\title{
Killer Cell Immunoglobulin-Like Receptor 2DS3
}

National Cancer Institute

\section{Source}

National Cancer Institute. Killer Cell Immunoglobulin-Like Receptor 2DS3. NCI Thesaurus. Code C132077.

Killer cell immunog lobulin-like receptor 2DS3 (304 aa, $\sim 34 \mathrm{kDa}$ ) is encoded by the human KIR2DS3 gene. This protein is involved in the positive regulation of natural killer cellmediated immunity. 